\title{
UNIONISATION AND FOREIGN DIRECT INVESTMENT: CHALLENGING CONVENTIONAL WISDOM?*
}

\author{
Dermot Leahy and Catia Montagna
}

\begin{abstract}
This paper investigates the effects of different degrees of wage setting centralisation on the incentive of a MNE to locate in a host country, and on the host country's welfare. Decentralised and centralised wage bargaining are considered. The nature of product market competition between the MNE and domestic firms proves crucial to results which cast doubt on some of the conventional wisdom on FDI. In particular, we show that: (i) it is not always welfare improving to attract inward FDI, and (ii) the MNE may prefer centralised to decentralised wage setting regimes.
\end{abstract}

The last few decades have witnessed a substantial growth of foreign direct investment (FDI). As a result, increasing attention has been devoted in policy debates to the welfare consequences of FDI for the host country and to the factors affecting multinationals' choice of location. A consensus seems to have emerged around some commonly accepted views which form a 'conventional wisdom' on FDI. Three of these conventional views are: (1) Inward FDI is welfare improving for a host country, regardless of the type of labour market institutions; (2) Multinational enterprises (MNEs) prefer decentralised firm level wage bargaining processes to centralised ones; (3) Governments should subsidise inward FDI, in particular in the presence of unionised labour markets.

The first of these conventional wisdoms concerns the welfare effects of FDI for the host country. Although different interest groups within an economy may hold conflicting views as to the desirability of inward FDI, it is probably appropriate to state that on balance governments see it as welfare improving. ${ }^{1}$ Thus, increasingly, 'international competitiveness' is not only meant to reflect the ability of a country to compete on international goods markets, but also its attractiveness to foreign MNEs.

The second conventional wisdom relates to the determinants of multinationals' choice of location, amongst which labour market characteristics and institutions are considered major factors. According to the emerging consen-

\footnotetext{
* We would like to thank David Collie, Nigel Driffield, Sajal Lahiri, Ben Lockwood, Robin Naylor, Peter Neary, Robert Read, Michele Santoni, Peter Sinclair, Ian Wooton, seminar participants at the Warwick CSGR and participants at the ESEM in Berlin, at the IESG-LSE meeting and at the Royal Economic Society Conference in Nottingham for comments on an earlier version of this paper. We are also indebted to three anonymous referees and to Alison Booth for helpful suggestions. The usual disclaimer applies.

1 Typical benefits associated with inward FDI are increased employment, technological externalities, emergence of new and/or more dynamic sectors, procompetitive effects on industry structure. Amongst its costs is the excessive competitive pressure on home firms which may force them out of business rather than stimulate their efficiency. Furthermore, as Zhao (1995) and Lahiri and Ono (1997) point out, the possible emergence of cross-hauling in FDI, may induce an 'export of jobs' thus outweighing the creation of new jobs by the inward FDI.
} 
sus, MNEs prefer flexible non-unionised labour markets and, when unionisation is in place, decentralised firm level wage bargaining processes over centralised ones. Despite ample empirical evidence (UN Investment Report, 1997) suggesting that labour costs are just one of the many considerations behind MNEs' location decisions, this view rests on the assumption that they are crucial in determining countries' ability to compete for FDI: by increasing labour costs, unionisation is detrimental to a country's attractiveness to MNEs. This type of argument has often been used in relatively highly unionised industrialised countries to endorse legislation aimed at limiting unions' power and deregulating the bargaining process.

The third conventional wisdom is almost a corollary of the other two. The desirability of inward FDI suggests the need for subsidising it, in particular when unionised labour markets are likely to make a host country less attractive to foreign MNEs. It is in fact common practice for national governments to subsidise and to compete for inward FDI. ${ }^{2}$

This paper attempts to evaluate the conventional wisdom outlined above in the context of unionised labour markets.

The interaction between labour market unionisation and FDI has received surprisingly little attention in the theoretical literature where the two have mostly been studied separately. A notable exception is Zhao (1995, 1998) where cross-hauling FDI is generated between two countries with imperfectly competitive product markets and unionised labour markets. Naylor and Santoni (1998) analyse the effects of union power and degree of substitutability between products on FDI.

Within the unionisation-FDI literature, our paper is the first of which we are aware to: (1) examine whether the degree of centralisation of union bargaining matters for MNEs' incentives to locate in a host country and for the policy towards FDI when unions extract rents from MNEs; $;^{3}$ and (2) study the role of different modes of product market interaction between MNEs and domestic firms. The focus of our analysis may be especially relevant to Europe where labour markets are generally highly unionised but where the degree of centralisation varies greatly across countries (Freeman and Katz, 1995) and where countries are characterised by different patterns of inwards FDI (Barrel and Pain, 1997).

We consider two alternative wage setting regimes. The first is decentralised, with trade unions bargaining individually with each firm. In the second a centralised union sets the wage(s) for an industry or group of industries.

Our analysis shows that the results crucially depend on the nature of product market interaction between the MNE and the host country's firms. We consider two situations. In the first there is no product market interaction, and the MNE does not compete with home firms either in the domestic or in any other

2 Bond and Guisinger (1985) study the effects of regional incentive programmes on the location decisions of MNEs. Haaparanta (1996) analyses the effects of tax competition between two countries on the allocation of an exogenously given amount of FDI by a MNE between them.

${ }^{3}$ Bughin and Vannini (1995) were probably the first to highlight the rent-extracting role of unions with FDI. Their model, however, does not address any of these points.

(C) Royal Economic Society 2000 
market. This allows us to isolate the effects of wage determination on the host country's welfare and on the MNE's decisions. We subsequently allow for product market interaction, which could occur in either the domestic or in an export market. This is not an academic distinction but one which may be seen as reflecting the motives behind a MNE's decision to locate in a host country. When the latter is seen by the MNE as an export base, the absence of direct competition with domestic firms is a plausible assumption. This is more likely the smaller is the economic size of the host country relative to the MNE's export market. A typical example of this is Ireland: its high share of inward FDI, which could not be ascribed to the extent of its domestic market, has mainly occurred in sectors which did not have a significant presence of indigenous firms. If, however, the MNE is attracted by domestic sales, it is likely (particularly in relatively large industrialised countries) that it will face competition from the host country's firms.

The model is developed in the next section. Sections 2 and 3 look at the alternative product market interaction cases, carry out welfare comparisons across different regimes and discuss the implications for policy towards FDI. Section 4 concludes the paper.

\section{The Model Set-up}

Consider a multinational which may set up in a host country where $N$ symmetric domestic firms are already located. All firms (including the MNE) are unionised.

We model the interaction between agents as a three-stage game. In stage one, the MNE decides whether to locate in the host country. In stage two, unions choose the wages at which labour will be supplied to firms. The focus of our analysis is on comparing different wage setting regimes. To isolate their effect it is convenient to hold constant the relative bargaining power of unions. In this context, it is simplest to assume that unions are monopoly wage setters. Two alternative wage setting regimes are considered. The first is decentralised with the unions bargaining individually with each firm. In the second, the wage bargaining is concluded centrally and one wage is set for all firms in the country. We shall also allow for the possibility that the centralised union may set a different wage for the MNE. In stage three, firms choose their output levels. Two types of product market competition are analysed: (1) the home firms and the MNE do not compete in the product market and the MNE exports all of its output. In this case we shall also rule out competition between domestic firms; ${ }^{4}$ (2) domestic firms and the MNE all compete in the same market which may or may not be the home market itself.

Thus, with decentralised wage setting there is no link between the home firms and the MNE. However, when bargaining is centralised, the wage setting process represents such a link. With direct product market competition, the

4 As documented by Barry and Bradley (1997), this situation is broadly consistent with the Irish experience.

(C) Royal Economic Society 2000 
MNE and the domestic firms are connected via the product market even with decentralised bargaining.

The MNE has a revenue function $R^{*}\left(y, D^{*}\right)=y p^{*}\left(y, D^{*}\right)$ where $y$ and $p^{*}$ are the MNE's output and price and $D^{*}$ is the output of its competitors. The revenue function for a typical home firm will be $R_{i}\left(q_{i}, D^{i}\right)=q_{i} p_{i}\left(q_{i}, D^{i}\right)$ where $q_{i}$ and $p_{i}$ are its output and price, and $D^{i}$ is the output of all its competitors (this may include the multinational). In order to obtain definite results, we shall adopt linear demand functions.

If the MNE locates, it will hire labour at a wage $w^{*}$, set in stage two by the unions.

For a firm to prosper in a foreign environment, it will generally possess some firm specific advantages (Dunning, 1988). In this paper, we assume this firmspecific advantage to consist of a higher labour productivity, resulting for instance from technical superiority and/or higher capital intensity. ${ }^{5}$ The profit function of the multinational is then:

$$
\pi^{*}=R^{*}\left(y, D^{*}\right)-w^{*} L^{*}(y, \alpha)-F,
$$

where $L^{*}$ is the labour employed in its host country's operation and $F$ is a fixed cost which may include the cost of capital. In particular, we shall assume that the MNEs' constant labour input requirement is $\alpha=L^{*} / y \leqslant 1$.

The typical home firm's profit function is:

$$
\pi_{i}=R_{i}\left(q_{i}, D^{i}\right)-w^{i} L^{i},
$$

where $L^{i}=q_{i}$ is labour employed.

The firm-specific unions' utility functions for the the multinational and the typical home firm are respectively:

$$
U^{*}=\left(w^{*}-\bar{w}\right) L^{*}
$$

and

$$
U^{i}=\left(w_{i}-\bar{w}\right) L^{i}
$$

where $\bar{w}$ is the constant wage paid to non-unionised workers. ${ }^{6}$

The national welfare function is given by:

$$
W=C S+U^{*}+\sum_{i}^{n}\left(\pi_{i}+U^{i}\right),
$$

where consumer surplus (CS) is zero when firms only export and is positive when firms sell to home consumers.

The stage-three first-order conditions for the choice of output of the multinational and the typical home firm are respectively given by

$$
R_{y}^{*}-w^{*} \alpha=0
$$

\footnotetext{
5 Evidence suggests that MNEs typically have a higher productivity than domestic firms (e.g. Davies and Lyons, 1992, and Barry and Bradley, 1997).

${ }^{6}$ We assume that employment and wages have the same weights in the unions' utility functions. One could easily allow for different weights, but this would not yield many additional insights in this context.

(C) Royal Economic Society 2000
} 
and

$$
R_{q_{i}}-w^{i}=0 .
$$

In stage two the unions choose wages to maximise total labour rents. We assume a right-to-manage model where firms retain discretion over employment decisions.

First assume that wages are set on a decentralised basis by unions which are monopolists at the firm level. In this case the particular wage in the multinational sector will be $w^{*}=w^{m}$. The first-order condition for the union in the multinational is:

$$
\frac{\partial U^{*}}{\partial w^{m}}=\left(w^{m}-\bar{w}\right) \frac{\partial L^{*}}{\partial w^{m}}+L^{*}=0
$$

and that for a typical domestic firm's union is:

$$
\frac{\partial U^{i}}{\partial w^{i}}=\left(w^{i}-\bar{w}\right) \frac{\partial L^{i}}{\partial w^{i}}+L^{i}=0 .
$$

Instead, with centralised bargaining, a single wage is set to maximise the sum of the individual unions' utilities: $V=U^{*}+N U$. This implies the following first order condition:

$$
\frac{d V}{d w^{c}}=\left(w^{c}-\bar{w}\right) \frac{\partial \Lambda}{\partial w^{c}}+\Lambda=0
$$

where $w^{c}=w=w^{*}$ is the centralised wage and $\Lambda \equiv N L^{i}+L^{*}$ is total employment.

In stage one of the game, the MNE will locate if its profit $\pi^{*}$ is greater than a reservation profit $\bar{\pi}$ which is assumed to be exogenous and to reflect the profit opportunities of locating elsewhere. The exogeneity of $\bar{\pi}$ implies that the host country is small in the market for FDI.

\section{No Product Market Interaction}

In the absence of product market interaction between the MNE and the domestic firms, the MNE is assumed to export all its output.

\subsection{Decentralised Wage Setting}

When unions set wages on a decentralised basis the equilibrium values of wages are implicitly given by (8) and (9).

The linear demand functions facing the firms are:

$$
p^{*}=a-\frac{1}{s^{*}} y \text { and } p^{i}=a-\frac{1}{s_{i}} q_{i},
$$

where the parameter $s_{i}$ represents a typical home firm's market size, and $s^{*}$ is similarly defined for the multinational (in this case $D^{i}=D^{*}=0$ ). Symmetry 
among domestic firms implies that $s=s_{i} \forall i$ (but $s$ may differ from $s^{*}$ ). From (8) and (9) we then obtain:

$$
w^{m}=\frac{1}{2}\left(\bar{w}+\frac{a}{\alpha}\right)
$$

and

$$
w=\frac{1}{2}(\bar{w}+a),
$$

where $w$ is the symmetric domestic firms' wage. Given that $\alpha \leqslant 1$, it is obvious that $w^{m} \geqslant w$ : the higher relative labour productivity of the multinational enables its union to extract a higher wage than that extracted from domestic firms. ${ }^{7}$

\subsection{Centralised Wage Setting}

When the centralised unions choose a common wage for all firms in the industry, the equilibrium wage is implicitly given by (10) which, given (11), yields

$$
w^{c}=\frac{1}{2}\left[\bar{w}+\frac{a(\alpha+\Gamma)}{\alpha^{2}+\Gamma}\right],
$$

where $\Gamma \equiv N s / s^{*}$ is an inverse measure of the MNE's market size relative to the total of the market sizes of domestic firms and reflects the relative labour market importance of the multinational sector from the point of view of the unions. Equation (14) implies $d w^{c} / d \Gamma<0$ that is, the greater the relative market share of the MNE the higher is the centralised wage. Furthermore, it is easy to show that $w^{c}$ lies strictly between the two decentralised wages $\left(w^{m}\right.$ and $\left.w^{i}\right)$, as illustrated in Fig. 1.

Thus, the centralised wage is always lower than the decentralised wage paid by the multinational, because even in the absence of product market interaction, centralisation generates a labour market link between the MNE and the domestic firms. Taking this link into account, the unions choose to limit rent extraction from the $\mathrm{MNE}$, in order to maintain employment in the less efficient domestic sector. This also explains the seemingly paradoxical impact of a ceteris paribus increase in the labour productivity of the MNE on the centralised wage. Although it raises the potential for rent extraction from the MNE, a lower $\alpha$ does not always result in a higher centralised wage. It can be shown that if $\alpha$ is sufficiently low $d w^{c} / d \alpha>0$. This is because unions face a trade-off between wage and employment and a high $w^{c}$ will damage employment not only in the MNE but also in the domestic sector. To protect employment, the unions may choose to reduce the wage. This would not occur in the

\footnotetext{
7 This is consistent with the evidence that MNEs typically pay higher wages than their domestic counterparts (e.g. Driffield, 1996).
}

(C) Royal Economic Society 2000 


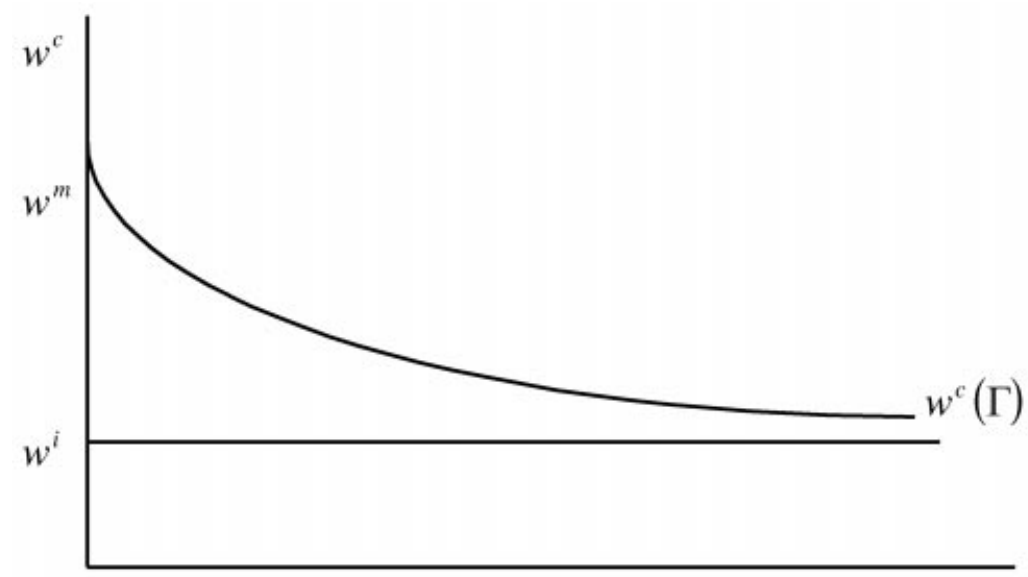

$\Gamma$

Fig. 1. The Centralised Wage without Product Market Interaction

decentralised case where the domestic sector is not a concern for the MNE's union.

\subsection{Welfare and Profits}

It is commonly argued that FDI is welfare improving for the receiving country. To assess this view we shall evaluate the welfare value of the MNE to the host country, defined as the ceteris paribus difference between the levels of welfare achieved with and without the MNE.

The conventional wisdom holds without market interaction, when the welfare value of FDI is positive regardless of the type of wage setting. It is easy to show that $W^{j}-W_{a}>0$ for $j=d$, $c$ where the superscript $j$ refers to the wage setting regime and the subscript $a$ refers to the absence of the MNE. ${ }^{8}$ The welfare value, however, is lower under centralised than under decentralised wage setting, because rent extraction from the MNE is lower with wage centralisation and there are negative spill-over effects of the higher centralised wage on domestic firms' profitability. It follows that the actual welfare level is higher under decentralised than under centralised wage setting (i.e. $\left.W^{d}>W^{c}\right)$.

The commonly held view that MNEs prefer firm-level wage setting processes to centralised ones is not supported by our analysis in the absence of direct product market competition with domestic firms, given that $w^{m}>w^{c}$ implies higher MNE's profits under centralised wage setting. Hence, a divergence of interests emerges between the MNE and the host country's government, with

8 Given the absence of market interaction, $W_{a}$ is identical under the two wage regimes.

(C) Royal Economic Society 2000 
centralised wage setting making entry more attractive to the MNE but leading to lower welfare levels.

The policy implication of this analysis is that when the MNE and the domestic firms do not directly compete with each other in the product market, it is desirable for a host country's government to attract inward FDI. In this case, the government will be willing to pay a lump-sum location subsidy up to the welfare value of the MNE. Clearly, the subsidy, which would be higher under decentralised wage setting, would only be required if $\pi^{*} \leqslant \bar{\pi}$.

\section{Product Market Interaction}

We now assume product market competition between the multinational and the domestic firms. Let firms produce an identical commodity, with the industry's inverse demand function given by

$$
p=a-b(Q+y),
$$

where $Q=\sum_{i}^{N} q_{i}$. Hence, in the MNE's revenue function $D^{*}=Q$, and in the revenue function of the typical home firm $D^{i}=y+\sum_{j \neq i}^{N} q_{j}$.

\subsection{Decentralised Wage Setting}

In the decentralised bargaining case unions play Nash, so when a typical home union $i$ chooses its wage $w^{i}$ it takes as given $w^{m}$ and the wages set by all other domestic unions $\left(w_{-i}\right)$. Symmetry implies that all domestic firms will face the same equilibrium wage (i.e. $w^{i}=w, \forall i$ ). Thus, using (8) and (9), we obtain the positively sloped reaction functions:

$$
w^{m}=\mu^{*}(w, \alpha) \text { and } w=\mu\left(w^{m}, \alpha\right),
$$

which define an equilibrium in wages.

It is straightforward to show that, although $d w^{m} / d \alpha<0$, the MNE's marginal $\operatorname{cost} c^{m}=\alpha w^{m}$ falls as labour productivity rises. Fig. 2 gives the locus of the multinational's marginal cost as a function of the marginal cost of domestic firms (MM) and the locus of the home firms' marginal cost as a function of the MNE's (HH). An exogenous decrease in $\alpha$ shifts the MM curve to the left and this results in a fall in both $c^{*}$ and $c\left(c^{*}\right.$ falls despite the fact that when $\alpha$ falls the union can extract higher wages). This improves the MNE's cost competitiveness relative to that of domestic firms and forces domestic firms' unions to accept a lower wage. ${ }^{9}$

\subsection{Centralised Wage Setting}

Under centralised bargaining the equilibrium wage is obtained from (10) which, given (15), yields

\footnotetext{
${ }^{9}$ It is straightforward to show that a fall in $\alpha$ commits the MNE to a higher output and reduces its rivals' output.

(C) Royal Economic Society 2000
} 


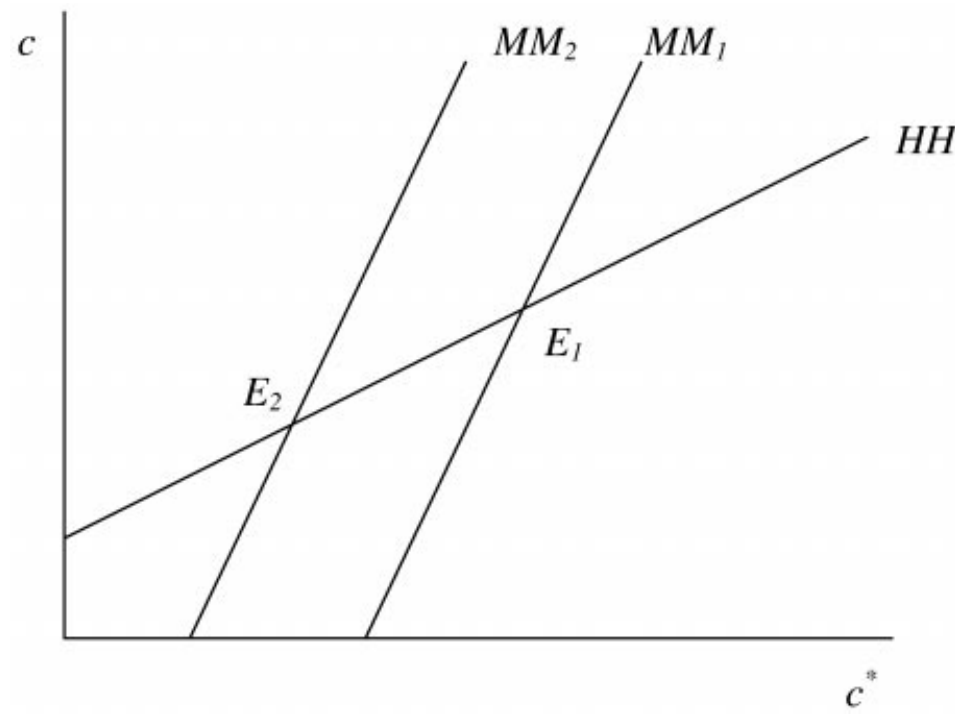

$$
\begin{aligned}
& c^{*}=\alpha w^{*} \\
& c=w
\end{aligned}
$$

Fig. 2. The Marginal Costs of the MNE and of a Typical Home Country Firm

$$
w^{c}=\frac{1}{2}\left[\bar{w}+\frac{a(\alpha+N)}{\alpha^{2}(N+1)+2 N(1-\alpha)}\right] .
$$

Contrary to the non-market interaction case when $w^{c}$ always lies below $w^{m}$, when the MNE competes with domestic firms in the product market we have $w^{c}>w^{m}$ for sufficiently large $N$ and $\alpha$. This is due to cooperative behaviour by the centralised unions which, by internalising product market externalities, set a higher wage. ${ }^{10}$

\subsection{Welfare and Profits}

With market interaction, when looking at the effects of inward FDI on the host country's welfare, it is important to distinguish between the cases in which firms do and do not sell in the domestic market.

\subsubsection{No domestic sales}

When firms are exporting only, the welfare value of inward FDI is negative under both decentralised and centralised wage settings, at least for $N>1$ (i.e., $W^{j}-W_{a}^{j}<0$ for $\left.j=d, c\right)$. This is because the introduction of a new (foreign)

${ }^{10}$ As in the no market interaction case, $d w^{c} / d \alpha$ will be positive for sufficiently large $N$ and small $\alpha$.

(C) Royal Economic Society 2000 
firm into the export sector of the economy has a negative effect on the terms of trade. ${ }^{11}$ At low $N$ and high $\alpha$ the welfare costs of a MNE entering the export sector are greater under decentralised bargaining, but this is reversed when the MNE is very productive ( $\alpha$ low), in which case the much higher centralised wage has serious negative consequences for the profitability of domestic firms.

Having considered the welfare values $\left(W^{j}-W_{a}^{j}\right)$, we turn to the discussion of welfare levels in order to determine the government's preferred bargaining regime, in the presence of FDI. We find that $W^{d}<W^{c}$ (for sufficiently large $\alpha$ and $N)$. This is because in this case $w^{c}>w^{m}$ and the higher centralised wage would act like an export tax: it yields rents to domestic residents (the unions) and it reduces output through an increase in the export price, moving the economy towards the monopoly output level. Despite the fact that $w^{c}>w^{m}$, it is straightforward to show that the MNE prefers to locate in the host country under centralised rather than under decentralised wage setting (except for $\alpha$ very close to unity), because in this case the higher centralised wage hurts its host country's rivals more than itself. Hence, for sufficiently large $\alpha$ and $N$ a congruence of interest applies between the MNE and the government, with both preferring the centralised wage setting regime.

\subsubsection{Firms sell domestically}

When firms are selling on the home market, the pro-competitive effect of the extra firm benefits consumer surplus. ${ }^{12}$ Nevertheless, the possibility of welfare gains is normally restricted to the decentralised wage setting case, with the welfare value of inward FDI being typically negative under wage centralisation, particularly for low $N$ and low $\alpha$. This is because the negative effects of the MNE on home firms via the centralised wage outweighs any gains to consumers.

Turning now from welfare values to welfare levels, we can show that $W^{d}>W^{c}$. With domestic sales, the tax-like effect of the higher centralised wage always results in welfare being higher under decentralised than under centralised wage setting. Thus, in contrast to the case in which firms export only, a conflict of interest between the MNE and the host country government would normally arise.

\subsubsection{The centralised firm specific wage setting}

It is worth noting that the centralised wage setting process considered so far assumes that the centralised union sets a single wage for all firms. However, the existence of labour productivity gaps between firms may encourage unions

11 Of course, if the MNE was already exporting into the foreign market, FDI would not introduce a new competitor and the welfare losses to the host country would be lower than here. The exact effect of this on welfare would depend on the cost competitiveness of the MNE's operation outside the home country. We ignore this possibility here because our concern is with cross comparisons between centralised and decentralised wage settings.

12 This pro-competitive benefit would be lower if the MNE already exported to the home market.

(C) Royal Economic Society 2000 
to set different wages for different firms cooperatively. ${ }^{13}$ Given the assumed symmetry of domestic firms, this would imply the setting of a single wage for the domestic firms and a different wage for the MNE. With no market interaction, this case collapses into the decentralised wage setting regime. With market interaction, the centralised union will exploit the higher productivity of the foreign firm by setting a MNE-specific wage which exceeds that paid by the host country's firms. This higher wage implies that the welfare value of the MNE would typically be positive when firms compete in the domestic market. This is in sharp contrast to the standard non-discriminatory centralised wage setting regime discussed above. Inward FDI would still typically be welfare reducing when firms compete in an export market (at least for sufficiently large $\alpha$ ). The losses, however, would be smaller than in the decentralised and standard centralised regimes.

\subsubsection{Comparison of market interaction with no-market interaction}

Except (i) in the 'centralised firm specific wage setting' case under market interaction, and (ii) when its productivity advantage is extremely small, the MNE will prefer a centralised wage setting regime (with and without market interaction), thus contradicting one of the conventional wisdoms mentioned in the introduction.

With respect to the welfare value of inward FDI, we find that direct product market competition makes welfare losses from inward FDI more likely, because the MNE will capture market shares from the indigenous firms, thus reducing their profits. This will have a direct adverse effect on welfare, not compensated by the entrant's profits which are repatriated. The fall in welfare will often be larger under wage centralisation because of the additional externality on domestic firms generated by the common industry wide-wage.

The overall policy implication of these results is that there are circumstances in which the government would prefer to prevent entry, unless it could raise a location tax at least equal to the negative 'welfare value' of FDI.

\section{Concluding Remarks}

This paper focuses on the nature of product market interaction between a MNE and domestic firms in examining the effects of different degrees of wage setting centralisation on the incentive of a MNE to locate in the host country and on the host country's welfare.

Our results suggest that there may be circumstances in which it will not be desirable for a government to encourage inward FDI. We find that negative welfare effects of FDI occur when there is direct product market competition between the MNE and the host country's firms. In this case the foreign MNE will effectively capture market shares from indigenous firms thus reducing their profits. This effect is shown to be particularly strong in the presence of

13 We are indebted to a referee for suggesting this case.

(C) Royal Economic Society 2000 
centralised wage setting processes. Hence, we highlight a channel through which inward FDI can have adverse effects on the host country's welfare. Clearly, in real world situations the net change in welfare would depend on many other factors (e.g. technical spill-overs from foreign firms). However, we believe that our findings, which cast at least some doubts on the general validity of the commonly held view that FDI is always welfare improving, are intuitive and are consistent with some of the empirical evidence on FDI (see Caves (1996) for a discussion of the effects of FDI on market structure and indigenous firms profitability). Therefore, our analysis points to the need for empirical research to disentangle the relative importance of this and of the other factors which determine the welfare effects of FDI on the receiving country.

We also show that, contrary to what is frequently argued, in the absence of taxes/subsidies, the MNE will be less likely to locate in the host country under a decentralised than under a centralised wage setting regime, despite the fact that the latter will typically yield higher wages.

Many natural extensions suggest themselves, such as technological spill-overs from MNEs to domestic firms, experimenting with different degrees of bargaining power of the unions, and examining cases in which the MNE can negotiate special union arrangements with the host country's government. Also, in the paper we have limited the policy analysis to direct, lump-sum polices towards the MNE; a richer menu of instruments, such as wage policies, are clearly worth considering. These topics are left for future research.

\section{University College, Dublin}

\section{University of Dundee}

\section{References}

Barrel R. and Pain N. (1997). 'The growth of foreign direct investment in Europe', National Institute Economic Review, issue 160, pp. 63-75.

Barry, F. and Bradley, J. (1997). 'FDI and trade: the Irish host-country experience'. ECONOMIC JourNAL, vol. 107, pp. 1798-811.

Bond, E. and Guisinger, S. (1985). 'Investment incentives as tariff substitutes: a comprehensive measure of protection', Review of Economics and Statistics, vol. 67, pp. 91-7.

Bughin, J. and Vannini, S. (1995). 'Strategic direct investment under unionised oligopoly', International Journal of Industrial Organisation, vol. 13, pp. 127-45.

Caves R. E. (1996). Multinational Enterprise and Economic Analysis, Cambridge, Cambridge University Press.

Davies, S. W. and Lyons, B. R. (1992). 'Characterising relative performance: the productivity advantage of foreign owned firms in the U.K.', Oxford Economic Papers, vol. 43, pp. 584-95.

Driffield, N. L. (1996). Global Competition and the Labour Market, Reading: Harwood.

Dunning, J. H. (1988). 'The eclectic paradigm of international production: a restatement of some possible extensions', Journal of International Business Studies, vol. 19, pp.1-29.

Freeman, R. B. and Katz, L. F. (1995). Differences and Changes in Wage Structures, Chicago: University of Chicago Press.

Haaparanta, P. (1996). 'Competition for foreign direct investment', Journal of Public Economics, vol. 63, pp. 141-53.

Lahiri, S. and Ono, Y. (1997). 'Tax policy on foreign direct investment in the presence of cross-hauling', University of Essex Discussion Paper No. 472.

Naylor, R. and Santoni, M. (1998). 'Wage bargaining and foreign direct investment', mimeo, University of Warwick.

(C) Royal Economic Society 2000 
United Nations (1997). World Investment Report: Transnational Corporation, Market Structure and Competition Policy, New York and Geneva.

Zhao, L. (1995). 'Cross-hauling direct foreign investment and unionised oligopoly', European Economic Review, vol. 39, pp. 1237-53.

Zhao, L. (1998). 'The impact of foreign direct investment on wages and employment', Oxford Economic Papers, vol. 50, pp. 284-301. 